\title{
Consumer perception about the influence of online retail service quality on e-satisfaction, moderated by purchase volume and perceived value \\ DVR.Subrahmanya Sastry.T \\ B. Madhusudhana Rao \\ School of Management Studies, \\ Vignan's University(Vfstr), Ap. India.
}

\begin{abstract}
Keywords:
Customer e-Satisfaction, Online Retailing, Online Customer, Online Retailer, Utilitarian Value, Hedonic Value.
\end{abstract}

\begin{abstract}
The Online retailing as a worldwide medium which is rapidly acquiring emphasis as the most advanced purchasing concept. Online purchasing for various consumers is being recognized as an innovative shopping mode compared to other modes of shopping. Understanding the influence of various service quality attributes on customer e-Satisfaction is very important for online vendors to bring-in suitable service strategies. If the vendors doing business in the online environment can analyze the factors influencing customer e-Satisfaction in online retailing and the relationship between these factors, then they can formulate influential strategies to retain existing customers for a longer period. This study is conducted to identify the association between the influential attributes and customer e-Satisfaction in the online retailing environment. The association between the service quality outcome and the perceived value attributes is analyzed in order to understand their influence on customer e-Satisfaction. The outcome of this study suggests that efficient implementation of web atmosphere by giving importance to both hedonic and utilitarian value can influence customer e-Satisfaction very proficiently in online retailing context.
\end{abstract}

Corresponding author: DVR. Subrahmanya Sastry.T

Email address for corresponding author: areandor@gmail.com

First submission received: 30th April 2017

Revised submission received: 2nd June 2017

Accepted: 5th July 2017

\section{Introduction}

In response to rising consumer needs, Online Retailers constantly need to develop new strategies to gain customers that are more loyal. The study of customer e-Satisfaction and various attributes of online retail shopping is gaining very importance due to the development of online shopping speedily. To achieve more sales, online retailers should adequately make consumers comfortable with their purchases in the online environment; to achieve this, an understanding of the influence of various attributes on customer e-Satisfaction is required with a special focus on online purchasing motive of the customer. This includes such things as, firstly, understanding how consumers prefer their shopping needs to be fulfilled especially in the online environment; these insights will strengthen the likelihood of their website being the desired platform for the customers for their shopping needs.

\section{Conceptual Overview}

Understanding the determinants of perceived value, customer satisfaction and repeat purchase intention is important for online vendors to plan their marketing strategies efficiently. Since online retailing is a new retailing format and online customer attitude is very different from a traditional customer; it is very important to recognize what influences the online customer to choose a website and consider it as a reliable shopping avenue. Establishing and maintaining loyalty is very 
fragile in online retailing, as the customer can easily switch from one website to another. Online consumer attitude towards shopping is influenced very strongly by both utilitarian and hedonic factors (Monsuwe, et al., 2004). Online consumers perceive hedonic and utilitarian value as important components in their preference while choosing any online retailer. Hedonic and utilitarian values have some role to play in consumer's intention of future purchases (Overby \& Lee, 2006). Buyers who purchase goods in online look for both hedonic and utilitarian values (Topaloglu, 2012).

\subsection{Customer e-Loyalty}

Customer e-loyalty can be understood as the behavioral intention of the customers to continuously purchase from the same website. Loyalty can be of significant value to both vendors and customers. Customer satisfaction positively influences the consumer e-Loyalty (Cristobal, et al., 2007). Customer e-Satisfaction is an essential requirement to gain e-Loyalty in the online environment (Valvi \& West, 2013). E-satisfaction and e-loyalty are very positively related (Moon, 2016). Customer's perception about the shopping value plays a very significant role in achieving customer e-Satisfaction and e-Loyalty ( $\mathrm{Li}$, et al., 2015). Online vendors should continuously improve transaction security, credibility, and prompt service dimensions to retaining existing customers for long-term and attract new customers (Lee \& Lin, 2005). Satisfied customers are very likely to become loyal to the vendor, expected to maintain the relationship for long-term and less likely to explore for alternatives. (Limbu, et al., 2011).

\subsection{Customer e-Satisfaction}

Customer e-Satisfaction occurs when the product and the associated retail services meet their expectations. Customer e-Satisfaction in online retailing context can be defined as the customer's valuation of that particular online retail website's service in terms of to what extent that meets their shopping needs and expectations. There is a substantial possibility that satisfied customers are expected to revisit the website and purchase repeatedly (Lien, et al., 2011). Improvement in the level of credibility, security, and quick services is required for both attracting new customers and retaining existing customers. These factors significantly influence customer e-Satisfaction and thereby purchase intention (Lee \& Lin, 2005). Satisfaction is defined as the comparison made by the consumer between the initial expectation on a product and what they get as a final result (Cristobal, et al., 2007). Customer satisfaction depends on the overall fulfilment of the expectations of the customer (Casalo, et al., 2008). Perceived value has the positive and direct association with customer satisfaction (Valvi \& West, 2013). Consumer shopping value shows a very significant influence on overall e-Satisfaction. Customization of products and services has significant importance to satisfy customer needs (Moon, 2016). It is very important for online retailers to create a very strong perceived value related to their products to satisfy the customers ( $\mathrm{Li}$, et al., 2015). The reliability aspect is a significant forecaster of purchase intention and customer satisfaction (Lee \& Lin, 2005). Ethical values are very important in online retailing. Non-deception has the power to influence customer satisfaction. Customer satisfaction can influence customer loyalty (Limbu, et al., 2011). Utilitarian value shows influence on customer satisfaction greatly (Sangkoy \& Tielung, 2015).

\subsection{Purchase Intention}

Online purchase intention can be defined as, the customer's willingness to get involved in some sort of online transaction to satisfy their shopping needs; it is one of the attributes of consumer's cognitive behaviour on how they plan to buy from a specific website. Re-purchase intention can be understood as the subjective probability that a customer will purchase from the same online vendor in future. Both utilitarian and hedonic values have the power to influence consumer purchase intention (Jang \& Shin, 2016). Online shopping experience shows significant influence on re-purchase intention (Chiu, et al., 2014). Maintaining favourable relationship with ecustomers, which can stay for long-term is very important. The online vendors should improve 
usefulness and self-efficacy; because these are the aspects valued greatly by the e-customer and will eventually boost their future purchase intention (Hernandez, et al., 2009). Both hedonic and utilitarian values show a very significant influence on consumer purchase intention in the online environment (Topaloglu, 2012).

\subsection{Perceived Value}

Consumer's overall valuation of the usefulness of a service based on the perception of what is received and what is given. Value can be defined as the increased benefits to the customer on the overall online transaction. Value-added strategies should be customer orientated and online vendors should identify whether they are positively valued by their customers and how their value perception influences e-Satisfaction. Any organization trying to provide competitive value to its customers should gain an in-depth understanding of the needs of the customer which can establish the value for the customer (Ravald \& Grönroos, 1996). There is a strong relationship among customer value, customer satisfaction and e-loyalty. It is suggested that online vendors should try to increase the benefits to their customers (Chang \& Wang, 2008). Online vendors to focus continuously on perceived value and customer satisfaction (Valvi \& West, 2013). Suggested that online retailers should improve shopping value which can boost e-Satisfaction and e-loyalty significantly (Moon, 2016).

\subsection{Utilitarian Value}

Utilitarian value can be defined as consumer's overall determination/assessment of functional benefits received and sacrifices. Utilitarian value is very much relevant for task-specific usage of online shopping channel, such as purchase consideration/deliberation and connected with the task-related value and the functional features of shopping. Consumers with utilitarian motive possess goal-oriented buying behaviour. Utilitarian buyers buy in online to meet a specific need or goal. Their most vital target in online purchasing is to purchase in very timely and efficient manner to achieve their shopping goals. Aspects such as enjoyment, self-gratification and social experiences are hedonic values of e-shopping. These hedonic aspects show some influence on consumer's shopping activities (Childers, et al., 2001). The utilitarian motive highlights goal-orientation, deliberate product procurement and impartial / rational where shopping is perceived as a necessity (Babin, et al., 1994). Consumers are very likely to do utilitarian purchase when they are considering more-than-one item to purchase together / simultaneously (Okada, 2005). Utilitarian value shows influence on customer loyalty (Sangkoy \& Tielung, 2015). Utilitarian value has the power to influence consumer purchase intention very strongly (Topaloglu, 2012). Utilitarian value can influence consumer purchase intention (Jang \& Shin, 2016).

\subsection{Hedonic Value}

Hedonic consumption in the online environment can be understood as the consumer behaviour which refers to the experience associated with the pleasure-oriented purchasing task. Hedonic value is viewed as emotional and experiential. Hedonic value is related to the consumer's shopping experience itself, rather than to the actual goods purchased. Consumers want to have pleasurable atmosphere when they do online shopping. The constructs relating to utilitarian and hedonic are not same, they should be seen separately (Voss, et al., 2003). Ease of shopping, competitive pricing, and greater access to information are related to utilitarian perspectives of online shopping. Hedonic motive relates to consumer shopping activity where the entertainment and fun of the shopping process may get a very prominent role while procuring the desired products (Childers, et al., 2001). Hedonic value to any customer focuses on playfulness and fun, representing the potential entertainment of shopping process and emotional benefit (Babin, et al., 1994). Consumers are very likely to do a hedonic purchase when they consider only one item to purchase singly (Okada, 2005). Hedonic value shows influence on consumer purchase intention indirectly 
(Topaloglu, 2012). Hedonic value can influence consumer purchase intention (Jang \& Shin, 2016). Consumers who browse hedonically show the highest frequency of purchasing (Scarpi, 2012).

\section{Literature Review}

Website credibility is very important for online vendors in order to attract customers to purchase from their web store and to gain more loyal customers (Fei \& Liat, 2015). Safety, credibility, security, continuity, etc, are very important. Ultimately these attributes can support and encourage customer satisfaction and loyalty. The ultimate aim of adding more value by the vendor is to increase customer satisfaction and loyalty. The vendor should provide the offerings to customers which they perceive as a greater net-value than the offerings of the other vendors in the market (Ravald \& Grönroos, 1996). To increase customer perceived value and customer satisfaction, online vendors should improve the design of the website, provide exact services, strengthen the security of the e-transactions, and provide sufficient help to customers to solve any challenges that they face (Chang \& Wang, 2008). Online vendors should improve the dimensions of reliability, such as the capability of delivering products as promised, providing recent and correct information, and strengthening the security of online transactions to boost purchase intention and customer satisfaction (Lee \& Lin, 2005). Customer's perception of hedonic and utilitarian values has the power to increase their reference towards a specific online shopping websites. Hedonic and utilitarian values influence e-satisfaction of online customers. Hedonic and utilitarian values can promote customer re-purchase intention significantly. Online retailers should provide a system which is easy to access, responds quickly to customers.

It is suggested to provide current information always which can be considered as utilitarian value to the customer. Providing diverse product information and speedy product delivery and quick returns mechanism are part of hedonic value (Kim, et al., 2012).Perceived value is an influential factor to e-Satisfaction and customer behavioural intention. Offering an extensive variety of products/services, evaluating price competition very cautiously, and easy ordering process are the ways to improve customer's overall perceived value (Lien, et al., 2011). Providing utilitarian value to the customer is largely under the control of the vendors. Online vendors should make sure that they provide sufficient utilitarian value. Buyers having successfully got the needed products from a particular online retailer, they will retain such a positive experience and are more likely to repurchase from the same website again. It is important to provide hedonic value to online buyers. Online vendors should ensure that they provide social interaction and keep up with new trends. Providing such benefits has the power to increase their re-purchase intention. Hedonic and utilitarian value has the direct influence on re-purchase intention (Chiu, et al., 2014).

\section{Research Methodology}

This research paper is confined to study the consumer perception about the perceived value and associated attributes of service quality in online retailing. The study is based on both primary and secondary data. The sample consists of consumers who bought goods in online retail websites. The data for the study was gathered through a self-administered questionnaire. Respondents are selected from both male and female population. These respondents belong to different income groups. A random sample of 203 respondents from different age groups is selected to carry out the current study. Due importance is given to a fact that the respondents should be online buyers. The analysis was conducted by using the statistical analysis tool SPSS version 19.0 in order to identify the factors affecting customer e-satisfaction and the role of hedonic and utilitarian value in the online retailing environment.

\subsection{Objectives of the study}

a) To study the importance of e-Satisfaction in Online Retailing.

b) To evaluate the role of perceived value in generating customer e-Satisfaction. 
c) To analyze association hedonic and utilitarian value with Customer e-Satisfaction in online retailing.

d) To offer possible suggestions relating to Customer e-Satisfaction in Online Retailing environment.

\subsection{Hypotheses}

H1: There is a significant relationship between purchase motive and perceived process quality.

H2: There is a significant relationship between purchase motive and perceived outcome quality.

H3: there is significant relationship between purchase volume and perceived process quality.

H4: there is a significant relationship between purchase volume and perceived outcome quality.

\section{Data analysis and inference}

\begin{tabular}{|l|c|c|c|c|c|c|}
\hline & \multicolumn{5}{|c|}{ Cases } \\
\hline & \multicolumn{2}{|c|}{ Valid } & \multicolumn{2}{c|}{ Missing } & \multicolumn{2}{c|}{ Total } \\
\hline $\begin{array}{l}\text { Purchase Volume * } \\
\text { Perceived Process Quality }\end{array}$ & N & Percent & N & Percent & N & Percent \\
\hline & 203 & 100 & 0 & 0.00 & 203 & 100 \\
\hline
\end{tabular}

Table 1: Data Processing Summary

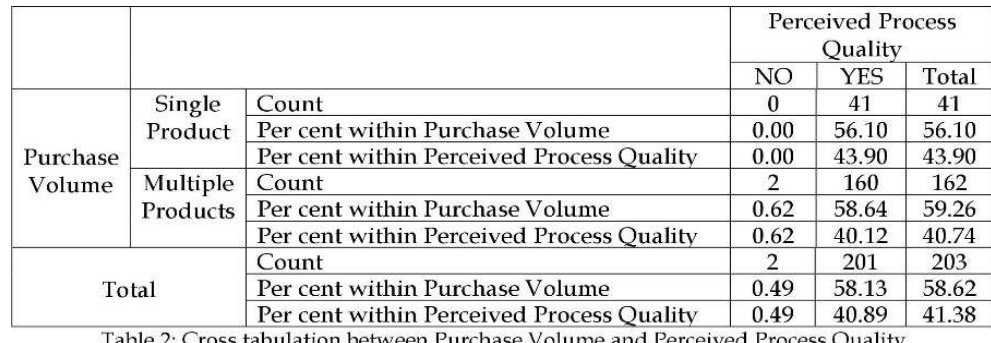

\begin{tabular}{|l|c|c|c|c|}
\hline & Value & df & $\begin{array}{c}\text { Asymp. Sig. } \\
\text { (2-sided) }\end{array}$ & $\begin{array}{c}\text { Exact Sig. } \\
\text { (2-sided) }\end{array}$ \\
\hline Pearson Chi-Square & $4.743^{\text {a }}$ & 4 & .315 & .392 \\
\hline Likelihood Ratio & 5.162 & 4 & .275 & .374 \\
\hline Fisher's Exact Test & 3.614 & & & .369 \\
\hline N of Valid Cases & 203 & & \\
\hline
\end{tabular}

\section{Inference:}

In order to test the hypothesis H1, Fisher's exact " $p$ " value is considered. It is found that the " $p$ " value is more than 0.05 ( $p>0.05)$, that indicates there is no significant correlation value between 'Purchase volume' and 'Perceived Process Quality'. So, it is clearly indicating to reject the Hypothesis H1. Hence, online buyers of any 'Purchase Volume' consider 'Process Quality' with similar importance.

\begin{tabular}{|c|c|c|c|c|c|c|c|c|}
\hline \multirow{3}{*}{\multicolumn{3}{|c|}{\begin{tabular}{|l|} 
\\
Purchase Volume * \\
Perceived Outcome Value
\end{tabular}}} & \multicolumn{6}{|c|}{ Cases } \\
\hline & & & \multicolumn{2}{|c|}{ Valid } & \multicolumn{2}{|c|}{ Missing } & \multicolumn{2}{|c|}{ Total } \\
\hline & & & $\mathrm{N}$ & Percent & $\mathrm{N}$ & Percent & $\mathrm{N}$ & Percent \\
\hline & & & 203 & 100 & 0 & 0.00 & 203 & 100 \\
\hline \multicolumn{9}{|c|}{ Table 4: Data Processing Summary } \\
\hline \multirow{2}{*}{\multicolumn{7}{|c|}{ 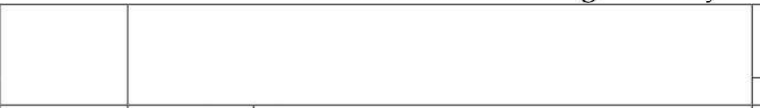 }} & \multicolumn{2}{|c|}{$\begin{array}{c}\text { Perceived Outcome } \\
\text { Quality }\end{array}$} \\
\hline & & & & & & & YES & Total \\
\hline \multirow{6}{*}{$\begin{array}{l}\text { Purchase } \\
\text { Volume }\end{array}$} & \multirow{3}{*}{$\begin{array}{l}\text { Single } \\
\text { Product }\end{array}$} & \multicolumn{3}{|l|}{ Count } & & 0 & 54 & 54 \\
\hline & & \multicolumn{4}{|c|}{ Percent within Purchase Volume } & 0.0 & 74.07 & 74.07 \\
\hline & & \multicolumn{4}{|c|}{ Percent within Perceived Quality } & 0.1 & 25.93 & 25.93 \\
\hline & \multirow{3}{*}{$\begin{array}{l}\text { Multiple } \\
\text { Products }\end{array}$} & \multicolumn{3}{|c|}{ Count } & & 3 & 146 & 149 \\
\hline & & \multicolumn{4}{|c|}{ Percent within Purchase Volume } & 0.6 & 63.76 & 64.43 \\
\hline & & \multicolumn{4}{|c|}{ Percent within Perceived Outcome } & $1.3^{3}$ & 34.23 & 35.57 \\
\hline \multirow{3}{*}{\multicolumn{2}{|c|}{ Total }} & \multirow{2}{*}{\multicolumn{3}{|c|}{ Count }} & & 3 & 200 & 203 \\
\hline & & \multirow{2}{*}{\multicolumn{4}{|c|}{$\begin{array}{l}\text { Per cent within Purchase Volume } \\
\text { Percent within Perceived Outcome }\end{array}$}} & 0. & \multirow{2}{*}{$\begin{array}{l}58.13 \\
40.89\end{array}$} & 58.62 \\
\hline & & & & & & 0.9 & & 41.87 \\
\hline
\end{tabular}

Table 5: Cross tabulation between Purchase Volume and Perceived Outcome Quality 


\begin{tabular}{|l|c|c|c|c|}
\hline & Value & df & Asymp. Sig. (2-sided) & Exact Sig. (2-sided) \\
\hline Pearson Chi-Square & $1.742^{\mathrm{a}}$ & 4 & .797 & .941 \\
\hline Likelihood Ratio & 2.795 & 4 & .635 & .923 \\
\hline Fisher's Exact Test & 1.679 & & & 1.00 \\
\hline N of Valid Cases & 203 & & & \\
\hline
\end{tabular}

\section{Inference:}

In order to test the hypothesis H2, Fisher's exact "p" value is considered. It is found that the " $\mathrm{p}$ " value is more than 0.05 ( $\mathrm{p}>0.05)$, that indicates there is no significant correlation value between 'Purchase volume' and 'Perceived Outcome Quality'. So, it is clearly indicating to reject the Hypothesis H2. Hence, online buyers of any 'Purchase Volume' consider 'Outcome Quality' with similar importance.

\begin{tabular}{|l|c|c|c|c|c|c|}
\hline & \multicolumn{5}{|c|}{ Cases } \\
\hline & \multicolumn{2}{|c|}{ Valid } & \multicolumn{2}{c|}{ Missing } & \multicolumn{2}{c|}{ Total } \\
\hline $\begin{array}{l}\text { Purchase Motive * } \\
\text { Perceived Process Qualitv }\end{array}$ & N & Percent & N & Percent & N & Percent \\
\hline & 203 & 100 & 0 & 0.00 & 203 & 100 \\
\hline
\end{tabular}

Table 7: Data Processing Summary

\begin{tabular}{|c|c|c|c|c|c|}
\hline & & & \multicolumn{3}{|c|}{$\begin{array}{c}\text { Perceived Process } \\
\text { Quality }\end{array}$} \\
\hline & & & NO & YES & Total \\
\hline \multirow{6}{*}{$\begin{array}{c}\text { Purchase } \\
\text { Motive }\end{array}$} & \multirow{3}{*}{$\begin{array}{l}\text { Hedonic } \\
\text { value } \\
\text { postulation }\end{array}$} & Count & 0 & 32 & 32 \\
\hline & & Per cent within Purchase Motive & 0.00 & 71.88 & 71.88 \\
\hline & & Per cent within Perceived Process & 0.00 & 28.13 & 28.13 \\
\hline & \multirow{3}{*}{$\begin{array}{c}\text { Utilitarian } \\
\text { value } \\
\text { postulation }\end{array}$} & Count & 05 & 166 & 171 \\
\hline & & Per cent within Purchase Motive & 1.17 & 70.76 & 71.93 \\
\hline & & Per cent within Perceived Process & 1.75 & 26.32 & 28.07 \\
\hline \multirow{3}{*}{\multicolumn{2}{|c|}{ Total }} & Count & 5 & 198 & 203 \\
\hline & & Per cent within Purchase Motive & 0.99 & 86.70 & 87.68 \\
\hline & & Per cent within Perceived Process & 1.48 & 10.84 & 12.32 \\
\hline
\end{tabular}

\begin{tabular}{|l|c|c|c|c|}
\hline & Value & df & Asymp. Sig. (2-sided) & Exact Sig. (2-sided) \\
\hline Pearson Chi-Square & 1.716 & 1 & .176 & .356 \\
\hline Likelihood Ratio & 2.941 & 1 & .059 & .239 \\
\hline Fisher's Exact Test & 1.653 & & & .315 \\
\hline N of Valid Cases & 203 & & \\
\hline \multicolumn{5}{|c|}{ Table 9: Chi-Square test results } \\
\hline
\end{tabular}

\section{Inference:}

In order to test the hypothesis H3, Fisher's exact " $p$ " value is considered. It is found that the " $\mathrm{p}$ " value is more than 0.05 ( $\mathrm{p}>0.05)$, that indicates there is no significant correlation value between 'Purchase Motive' and 'Perceived Process Quality'. So, it is clearly indicating to reject the Hypothesis H3. Hence, online buyers of any 'Purchase Motive' consider 'Perceived Process Quality' with similar importance.

\begin{tabular}{|l|c|c|c|c|c|c|}
\hline & \multicolumn{5}{|c|}{ Cases } \\
\hline & \multicolumn{2}{|c|}{ Valid } & \multicolumn{2}{c|}{ Missing } & \multicolumn{2}{|c|}{ Total } \\
\hline $\begin{array}{l}\text { Purchase Motive * } \\
\text { Perceived Outcome Quality }\end{array}$ & N & Percent & N & Percent & N & Percent \\
\hline & 203 & 100 & 0 & 0.00 & 203 & 100 \\
\hline
\end{tabular}

Table 10: Data Processing Summary 


\begin{tabular}{|c|c|c|c|c|c|c|c|}
\hline & & & & & \multicolumn{3}{|c|}{$\begin{array}{c}\text { Perceived Outcome } \\
\text { Quality }\end{array}$} \\
\hline & & & & & $\mathrm{NO}$ & YES & Total \\
\hline \multirow{6}{*}{$\begin{array}{l}\text { Purchase } \\
\text { Motive }\end{array}$} & \multirow{3}{*}{$\begin{array}{c}\text { Hedonic } \\
\text { value } \\
\text { postulation }\end{array}$} & \multicolumn{3}{|l|}{ Count } & 2 & 57 & 59 \\
\hline & & \multicolumn{3}{|c|}{ Percent within Purchase Motive } & 1.69 & 54.24 & 55.93 \\
\hline & & \multicolumn{3}{|c|}{ Percent within Perceived Outcome } & 1.69 & 42.37 & 44.07 \\
\hline & \multirow{3}{*}{$\begin{array}{l}\text { Utilitarian } \\
\text { value } \\
\text { postulation }\end{array}$} & \multicolumn{3}{|c|}{ Count } & 4 & 140 & 144 \\
\hline & & \multicolumn{3}{|c|}{ Percent within Purchase Motive } & 1.39 & 78.47 & 79.86 \\
\hline & & \multicolumn{3}{|c|}{ Percent within Perceived Outcome } & 2.08 & 18.75 & 20.83 \\
\hline \multirow{3}{*}{\multicolumn{2}{|c|}{ Total }} & \multicolumn{3}{|c|}{ Count } & 4 & 199 & 203 \\
\hline & & \multicolumn{3}{|c|}{ Percent within Purchase Motive } & 0.49 & 82.27 & 82.76 \\
\hline & & \multicolumn{3}{|c|}{ Percent within Perceived Outcome } & 1.48 & 15.76 & 17.24 \\
\hline \multicolumn{8}{|c|}{ Table 11: Crosstabulation between Purchase Motive and Perceived Outcome Quality } \\
\hline & & Value & & Asymp. Sig.(2-sided) & \multicolumn{3}{|c|}{ Exact Sig. (2-sided) } \\
\hline \multicolumn{2}{|c|}{ Pearson Chi-Square } & $.734^{\mathrm{a}}$ & 1 & .392 & \multicolumn{3}{|c|}{.509} \\
\hline \multicolumn{2}{|c|}{ Likelihood Ratio } & 1.549 & 1 & .275 & \multicolumn{3}{|c|}{.549} \\
\hline \multicolumn{2}{|c|}{ Fisher's Exact Test } & 1.176 & & & \multicolumn{3}{|c|}{.329} \\
\hline \multicolumn{2}{|c|}{ N of Valid Cases } & 203 & & & & & \\
\hline
\end{tabular}

\section{Inference:}

In order to test the hypothesis H4, Fisher's exact " $p$ " value is considered. It is found that the " $\mathrm{p}$ " value is more than $0.05(\mathrm{p}>0.05)$, that indicates there is no significant correlation value between 'Purchase Motive' and 'Perceived Outcome Quality'. So, it is clearly indicating to reject the Hypothesis H4. Hence, online buyers of any 'Purchase Motive' consider 'Perceived Outcome Quality' with similar importance.

\section{Findings}

The current study empirically examined one of the important constructs of consumer perceived value in the context of online retailing. This consists of two vital elements: 'Perceived Process Quality' and 'Perceived Outcome Quality'. Consumer 'Perceived Value' is considered in the current study as a moderating factor for analyzing the quality attributes of online retail service. Purchase volume is taken as the second moderating factor to analyze the quality attributes of online retail service. It is found that online buyers with both hedonic and utilitarian shopping motives prefer 'Process Quality' with similar importance. Buyers buying goods with both hedonic and utilitarian shopping motives prefer 'Outcome Quality' with similar importance in online retailing. Both the groups of buyers of a single item and multiple items prefer the 'Outcome Quality' with similar significance. Process Quality has got alike importance from both the groups of buyers who bought singe item and multiple items in the online retail environment.

\section{Discussion}

The results of the current study indicate that motivation of any consumer to engage in online purchasing includes both hedonic and utilitarian dimensions. Ease of use and usefulness demonstrate the utilitarian aspects of online shopping of the consumer. Enjoyment and fun illustrate the hedonic aspect of consumer motivation in online shopping. It is fairly important to provide similar kind of quality outcome to consumers whether the purchase volume is small or huge as it can influence re-purchase intention. The way online retailers deliver products, which is associated with the perceived outcome quality shows influence on the willingness of customers to return to the same retail website for their future shopping needs. Order fulfilment is an essential part of the consumer perceived outcome quality and plays very important role in generating higher perceived value and customer satisfaction. Customer e-Satisfaction is very important for online vendors as it can result in generating loyal customers. It can be achieved by providing very high level of product/service value (Yang \& Peterson, 2004). Creating a positive value for customer purchase is an important factor or retaining customers for long-term. The online vendor should design strategies to improve trustworthiness, the aspects related to reliability and very importantly responsiveness feature to 
enhance customer purchase intention (Lee \& Lin, 2005). It is identified that customer e-Satisfaction influences e-Loyalty significantly (Ngamkroeckjoti \& Zhao, 2014). Consumers/shoppers choose the online mode of purchases mainly for the utilitarian reasons, such as price saving and ease of shopping (Overby \& Lee, 2006). It can be understood that utilitarian value has a lot of importance for the buyer and is profitable to the vendor in online market (Scarpi, 2012).

\section{Conclusion}

To understand the consumer perceived value, we tried to link the utilitarian and hedonic dimensions of consumer buying attitude. Consumer perceived value has a significant role in influencing consumer attitude towards the website and ultimately the purchase intention. Consumer's value derived in any shopping experience includes both hedonic and utilitarian benefits. The main aim of this study is to analyze the association between various attributes and their relative influence on customer e-Satisfaction. It is found that customer e-Satisfaction in online retail context is very important to retain customers for long-term. It is very essential that online shopping values should be assessed by considering the role of both utilitarian and hedonic aspects. Consumer perceived value shows significant influence on customer satisfaction and re-purchase intention in the online shopping environment. Perceived value has a positive and strong association with online retailing services (Mwencha, et al., 2014). Enhancement in the level of security, credibility, and prompt services is required for both attracting and retaining e-customers, since these factors significantly influence purchase intention and customer satisfaction (Lee \& Lin, 2005). Both hedonic and utilitarian values are the fundamental elements that support to understand consumer's assessment of the overall experience of their consumption (Vinerean, et al., 2015). Assured transaction security in response to perceived payment risk provided by online vendors may reduce consumer's perceived risk and increase their purchasing potential in online (Zheng, et al., 2012). To achieve customer satisfaction, it is suggested that online vendors should establish good measures for handling returned products (Lim, 2003). Posting explicit policies of security and privacy on the website by online vendors helps in gaining customer trust and loyalty (Hwang, et al., 2012). There is a substantial association between hedonic value and consumer's intention to revisit the same website for future purchase requirements (Scarpi, 2012).

The online retailers should incorporate animated images and aesthetically pleasing layouts with attractive colors to provide hedonic value to consumers. Effective and interesting product commentary with animated product representation can add value as potential hedonic features in online retailing. It is suggested that online retailers should constantly engage consumers by sending visually appealing emails with attractive content as a productive marketing strategy.

\section{Recommendations}

Online vendors should give importance to both hedonic and utilitarian value while designing retail service quality mechanism. It is very important for online vendors to consider the attributes of hedonic value while designing marketing strategies to attract various segments of customers in the competing market conditions. Providing quality outcome is essential to create a superior value to the consumer which can influence consumer buying behavior and re-purchase intention. The quality of delivered services formulates value for utilitarian facets of shopping. It is suggested that online vendors should invest all the possible effort to enhance the quality of their system, quality of information and quality of service to satisfy customer's hedonic and utilitarian values, which can ultimately lead to the success of their business (Kim, et al., 2012). Online retailers should give importance to both functional and hedonic values while designing and delivering to customers (Mwencha, et al., 2014). Online retailers should design their website by giving importance to the features, which can strengthen their user's hedonic potential (Scarpi, 2012). Online vendors should offer mistake-free services and security to online transactions to ensure that customers are comfortable using online shopping (Lee \& Lin, 2005). Perceived value is an influential factor of 
customer e-Loyalty. It significantly influences customer e-Satisfaction in the online context (Yang \& Peterson, 2004). Online Vendor should improve the dimensions of reliability such as delivering goods as per the promise, presenting latest and accurate information to enhance customer eSatisfaction. Online transaction security is one of the important factors to gain customer eSatisfaction. It is suggested to strengthen online transaction security in the online environment (Lee \& Lin, 2005).

The primary focus of any online retailer should be achieving a higher level of customer eSatisfaction. Strong ethical standards such as security and fulfilment can be considered as the significant elements of customer e-Satisfaction. These factors can influence positively the online customer attitude and buying intention, possibly lead to the improved frequency of repeat purchases (Limbu, et al., 2011). Online vendors that desire long-term customer loyalty should ensure that customers are satisfied with the website. It is suggested to provide the customers with a great shopping value (Ngamkroeckjoti \& Zhao, 2014). It is very important for online retailers to provide sufficient utilitarian value to their customers (Overby \& Lee, 2006). Online vendors should consider incorporating image with interactive features to the retail website. Image interactivity feature is very important to increase customer's approach response, such as willingness to buy from that website. More importantly, it has the power to encourage customers to re-purchase intention (Fiore, et al., 2005).

\section{Limitations and Scope for Future Research}

The current study is conducted is limited to the online buyers of the study area and can't be generalized to the entire population in the online market. Another limitation is this study did not consider the purchase frequency as a factor to analyze the consumer perceived value. Further research on the measurement of the hedonic and utilitarian constructs can focus on developing measurement framework which may be applied to a wide range of consumer attitudinal elements beyond the perceived value and attitude towards website alone. In addition to purchase volume, other potential moderators include product type, gender; as they can influence online consumer behaviour. Analyzing hedonic and utilitarian motive with purchase frequency as the moderating factor can bring more insights on consumer intention in the online environment. Purchase volume is one of the potential factors to be analyzed; which can be examined with both consumer hedonic and utilitarian values.

\section{References}

Babin, B. R., William, D. R. \& Mitch, G., 1994. Work and/or fun: Measuring hedonic and utilitarian shopping value. Journal of consumer research, 20(4), pp. 644-656.

Casalo, L., Flavian, C. \& Guinalıu, M., 2008. The role of perceived usability, reputation, satisfaction and consumer familiarity on the website loyalty formation process. Computers in Human Behavior, Volume 24, p. 325-345.

Chang, H. H. \& Wang, H.-W., 2008. The Relationships among e-Service Quality, Value, Satisfaction and Loyalty in Online Shopping. European Advances in Consumer Research, Volume 8, pp. 10-14.

Childers, T. L., Carr, C. L., Peck, J. \& Carsond, S., 2001. Hedonic and utilitarian motivations for online retail shopping behavior. Journal of Retailing, Volume 77, p. 511-535.

Chiu, C.-M., Wang, E. T. G., Fang, Y.-H. \& Huang, H.-Y., 2014. Understanding customers' repeat purchase intentions in $\mathrm{B} 2 \mathrm{C}$ e-commerce: the roles of utilitarian value, hedonic value and perceived risk. Information Systems Journal, 24(1), p. 85-114.

Cristobal, E., Flavian, C. \& Guinalıu, M., 2007. Perceived e-service quality (PeSQ) Measurement validation and effects on consumer satisfaction and website loyalty. Managing Service Quality, 17(3), pp. 317-340.

Fei, Y. M. \& Liat, B. C., 2015. Factors Affecting Consumer's Continuance Online Purchase Intention in Malaysia. Global Journal of Business and Social Science Review, 1(1), pp. 309-321. 
Fiore, A. M., Jin, H.-J. \& Kim, J., 2005. For Fun and Profit: Hedonic Value from Image Interactivity and Responses Toward an Online Store. Psychology \& Marketing, 22(8), p. 669-694.

Hernandez, B., Jimenez, J. \& Martın, M. J., 2009. Adoption vs acceptance of e-commerce: two different decisions. European Journal of Marketing, 43(9/10), pp. 1232-1245.

Hwang, D., Preiser-Houy, L. \& Shang, R. A., 2012. A comprehensive framework for online store functionalities. Issues in Information Systems, 13(2), pp. 336-345.

Jang, S.-H. \& Shin, J.-I., 2016. The Influence of Contextual Offer, Utilitarian, and Hedonic Value on Purchase Intention in Mobile Location-Based Services. International Journal of Business Policy and Strategy Management, Volume 3, pp. 7-12.

Kim, C. et al., 2012. Factors influencing Internet shopping value and customer repurchase intention. Electronic Commerce Research and Applications, Volume 11, p. 374-387.

Lee, G.-G. \& Lin, H.-F., 2005. Customer perceptions of e-service quality in online shopping. International Journal of Retail \& Distribution Management, 33(2), pp. 161-176.

Lien, C.-H., Wen, M.-J. \& Wu, C.-C., 2011. Investigating the Relationships among E-Service Quality, Perceived Value, Satisfaction, and Behavioral Intentions in Taiwanese Online Shopping. Asia Pacific Management Review, 16(3), pp. 211-223.

Li, H., Aham-Anyanwu, N., Tevrizci, C. \& Luo, X., 2015. The interplay between value and service quality experience: e-loyalty development process through the eTailQ scale and value perception. Electronic Commerce Research, 15(4), pp. 585-615.

Limbu, Y. B., Wolf, M. \& Lunsford, D. L., 2011. Consumers' perceptions of online ethics and its effects on satisfaction and loyalty. Journal of Research in Interactive Marketing, 5(1), pp. 71-89.

Lim, N., 2003. Consumers' perceived risk: sources versus consequences. Electronic Commerce Research and Applications, 2(3), pp. 216-228.

Monsuwe, Y. T. P., Dellaert, B. G. \& Ruyter, K. d., 2004. What drives consumers to shop online? A literature review. International Journal of Service, 15(1), pp. 102-121.

Moon, Y. J., 2016. Consumer's Shopping Values for e-Satisfaction and e-Loyalty: Moderating Effect of Personality. International Journal of $u$ - and e-Service, Science and Technology, 9(2), pp. 331-342.

Mwencha, P. M., Muathe, S. M. \& Thuo, J. K., 2014. Effects of Perceived Attributes, Perceived Risk and Perceived Value on Usage of Online Retailing Services. Journal of Management Research, 6(2), pp. 140-161.

Ngamkroeckjoti, C. \& Zhao, X., 2014. Determinant factors of e-loyalty: A case study of the advertising shown on Facebook page of Durex, Thailand. Issues in Business Management and Economics, 2(8), pp. 134-141.

Okada, E. M., 2005. Justification Effects on Consumer Choice of Hedonic and Utilitarian Goods. Journal of Marketing Research, Volume XLII, p. 43-53.

Overby, J. W. \& Lee, E.-J., 2006. The effects of utilitarian and hedonic online shopping value. Journal of Business Research, Volume 59, p. 1160-1166.

Ravald, A. \& Grönroos, C., 1996. The value concept and relationship marketing. European Journal of Marketing, 30(2), pp. 19-30.

Sangkoy, N. V. \& Tielung, M. V. J., 2015. The effect of utilitarian value and hedonic value on teenagers customer loyalty at manado town square. Journal of Economic Research, Management, Business and Accounting, 3(3), pp. 709-718.

Scarpi, D., 2012. Work and Fun on the Internet: The Effects of Utilitarianism and Hedonism Online. Journal of Interactive Marketing, Volume 26, p. 53-67.

Topaloglu, C., 2012. Consumer motivation and concern factors for online shopping in Turkey. Asian Academy of Management Journal, 17(2), p. 1-19.

Valvi, A. C. \& West, D. C., 2013. E-Loyalty is not all about Trust, Price also matters: Extending expectation-confirmation theory in bookselling websites. Journal of Electronic Commerce Research, 14(1), pp. 99-123. 
Vinerean, S., Opreana, A., Cetina, I. \& Dumitrescu, L., 2015. Relationships among Hedonic and Utilitarian Factors and Exogenous and Endogenous Influences of Consumer Behavior in Tourism. Expert Journal of Marketing, 3(1), pp. 17-28 .

Voss, K. E., Spangenberg, E. R. \& Grohmann, B., 2003. Measuring the Hedonic and Utilitarian Dimensions of Consumer Attitude. Journal of Marketing Research, Volume XL, p. 310-320.

Yang, Z. \& Peterson, R. T., 2004. Customer Perceived Value, Satisfaction, and Loyalty: The Role of Switching Costs. Psychology \& Marketing, 21(10), p. 799-822.

Zheng, L., Favier, M., Huang, P. \& Coat, F., 2012. Chinese consumer perceived risk and relievers in eshopping for clothing. Journal of Electronic Commerce Research, 13(3), pp. 255-274. 